\title{
Article \\ Development of Renewable Energy Sources in the European Union in the Context of Sustainable Development Policy
}

\author{
Piotr Bórawski 1,*(D), Rafał Wyszomierski ${ }^{2}\left(\mathbb{D}\right.$, Aneta Bełdycka-Bórawska $^{1}(\mathbb{D})$ Bartosz Mickiewicz $^{3}$ MD $^{\text {, }}$ \\ Beata Kalinowska ${ }^{1}$ (D), James W. Dunn ${ }^{4}$ and Tomasz Rokicki ${ }^{5}$ (D)
}

1 Department of Agrotechnology and Agribusiness, Faculty of Agriculture and Forestry, University of Warmia and Mazury in Olsztyn, 10-719 Olsztyn, Poland; aneta.beldycka-borawska@uwm.edu.pl (A.B.-B.); kalibeti@gmail.com (B.K.)

2 Faculty of Economics and Management, Higher School of Agribusiness in Lomza, 18-402 Lomza, Poland; rafal_wyszomierski@wp.pl

3 Faculty of Economics, West Pomeranian University of Technology, 70-310 Szczecin, Poland; bartosz.mickiewicz@zut.edu.pl

4 Department of Agricultural Economics, Sociology and Education, Faculty of Agricultural Sciences, Pennsylvania State University, University Park, State College, PA 16802-5600, USA; jwd6@psu.edu

5 Department of Logistics, Institute of Economics and Finance, Warsaw University of Life Sciences, 02-787 Warsaw, Poland; tomasz_rokicki@sggw.edu.pl

* Correspondence: pboraw@uwm.edu.pl; Tel.: +48-698014056

check for updates

Citation: Bórawski, P.; Wyszomierski, R.; Bełdycka-Bórawska, A.; Mickiewicz, B.; Kalinowska, B.; Dunn, J.W.; Rokicki, T. Development of Renewable Energy Sources in the European Union in the Context of Sustainable Development Policy. Energies 2022, 15, 1545. https:// doi.org/10.3390/en15041545

Academic Editor: Behnam Zakeri

Received: 29 January 2022

Accepted: 17 February 2022

Published: 19 February 2022

Publisher's Note: MDPI stays neutral with regard to jurisdictional claims in published maps and institutional affiliations.

Copyright: (C) 2022 by the authors. Licensee MDPI, Basel, Switzerland. This article is an open access article distributed under the terms and conditions of the Creative Commons Attribution (CC BY) license (https:// creativecommons.org/licenses/by/ $4.0 /)$.

\begin{abstract}
Renewable energy sources play a key role in decarbonizing the economy of the European Union (EU) and the world. The aim of this research is to present the development of the renewable energy sources (RES) sector in the European Union (EU), with particular emphasis on sustainable development. The EU guidelines, requirements, and directives were analyzed in order to meet the provisions of the energy policy to ensure energy and climate security. The potential of the RES was studied in the EU countries, and the possibility of its use in cogeneration with the use of local renewable resources. The results are presented in tabular, graphic, and descriptive forms. The results are presented based on the extensive literature on the subject and data from Eurostat. The data covered 2004-2019. We used different methods to evaluate the changes in the RES in the EU countries. First, we compiled descriptive statistics; second, we used the Augmented Dickey-Fuller test (ADF test); and, finally, we used the Generalized Autoregressive Conditional Heteroscedasticity model (GARCH model). Our analysis found that the EU increased the share of RES. The biggest share of energy from renewable energy sources was found in 2019 in Iceland (78\%), Norway (74\%), and Sweden (56\%). The biggest increase in the share of RES in 2004-19 was found in Malta (8322\%), Great Britain (1126\%), and Luxemburg (784\%). The results demonstrate the development of RES in the EU countries. However, not all countries achieved the planned goal in 2019.
\end{abstract}

Keywords: renewable energy sources; sustainable development; energy sector

\section{Introduction}

Total global energy consumption has been increasing. The consumption of total market energy will increase from 2012 to 40 by 48\% [1,2]. Lower supplies of fossil fuels are attracting growing interest in alternative energy sources, such as wind energy, biomass, sun energy, geothermal energy, and waterpower [3].

Renewable energy sources (RES) play a key role in decreasing carbon dioxide and other harmful gasses [4]. To decrease the temperature by 20 degrees $C$, the world will need to increase the share of RES from 19\% in 2017 to $65 \%$ in 2050 [5].

Accordingly, the basic directions of European energy policy are: improve energy efficiency; increase the security of fuel and energy supplies; diversify the electricity generation structure, including by introducing nuclear energy; develop the use of renewable energy 
sources, including biofuels; develop competitive fuel and energy markets; reduce the impact of the energy sector on the environment [6]; use its own energy resources optimally; expand electricity generation and grid infrastructure; diversify natural gas and crude oil supplies; expand the network infrastructure; and develop heating and cogeneration capacity [7].

The threat to the energy security of each country and the entire EU is not due to the mere fact of importing fuels, but because of the poor structure of these imports, unreliable and dishonest suppliers, unfavorable prices, or unfavorable contract clauses. Both the structure of the fuel balance and the necessary importing of fuels should be optimized with economic criteria and the need to protect the natural environment (sustainable development), while taking into account the requirement of maximum energy security [8].

The basic elements of sustainable development in energy policy, which closely cooperate with each other, are: energy security management; guarantee of continuity for energy supplies; guarantee of the production potential of energy and the use of domestic sources; environmental protection; energy efficiency of the economy; research and development works; international cooperation [9,10]; supporting the development of renewable energy sources; and obtaining a 23\% share of energy in gross final energy consumption in 2030 and $28.5 \%$ in 2040 [7].

Solving the emerging problems related to energy security is a main goal of sustainable development. The key issues for its assessment are the availability of adequate fuel resources and the net international exchange of energy. Diversification of energy supplies, development of distributed energy, and reliability and continuity of supplies are not only elements associated with increasing the economic security of energy development, but also have a significant impact on the prices of energy and its carriers. They shape competition between suppliers on the domestic market, which may contribute not only to lowering prices, but also to their differentiation [11]. After all, one of the basic arguments of energy security is independence from other countries [12].

The aim of the article is to present the idea of the development of the renewable energy sector in Europe in relation to sustainable development. The detailed aims are as follows:

1. The recognition of renewable energy sources in the EU.

2. The evaluation of the development of RES in the EU.

To achieve this goal, we aimed to answer the following questions:

1. What is the share of RES in the EU?

2. What is the proportion of the use of individual energy carriers in the EU?

3. What should be the basic directions of the EU energy policy in order to achieve sustainable development?

4. What should be the basic elements of sustainable development in energy policy?

5. What is the assessment of the condition of the energy sector?

Hypothesis 1 (H1). The share of renewable energy sources is diversified regionally and it is increasing as the effect of environmental policy in the European Union (EU).

Hypothesis 2 (H2). The renewable energy sources (RES) increase the sustainable development of countries, and particularly enhance environmental issues.

The paper is organized as follows. First, we present the concepts of sustainable development, renewable energy, and related policy. Second, we present the methodology. The third section describes the research results. Next, we present the discussion. The final part presents our conclusion. 


\section{Renewable Energy Sources in the Context of Sustainable Development}

\subsection{Sustainable Development Concept}

Sustainability is a very broad concept having different definitions and interpretations [13]. The beginning of the creation of the concept of sustainable development was in the 18th century. The catalyst was the struggling German timber industry, in which the concept of sustainable development arose to stimulate and help the industry survive.

Later, it was extended to fisheries and mining as a result of realizing that natural resources are limited and therefore require controlled and rational use. The 1960s also saw restrictions on the overexploitation of the seas and oceans, the use of herbicides in agriculture, and the intensity of agricultural production, which can cause irreversible damage to standards and the ecological balance [14].

The aim of balanced and sustainable development is to meet the needs of the present generation without diminishing the chances of future generations to meet them. This definition of sustainable development was first given in the 1987 Report of the World Commission on Environment and Development (Brutland Report) entitled: "Our Common Future", followed by the programming document in 1992 (Agenda 21) entitled: "Environment and Development" [15]. This concept is now considered to be one of the most important concepts of economic development [16]. This means that the economic and civilization development of the current and future generations cannot take place by depletion of non-renewable resources and destruction of the environment [17]. This development should take place comprehensively, based on individual sectoral policies of states [12]. In Poland, sustainable development was defined for the first time in the Act on the protection and shaping of the environment of 31 January 1980 [18].

The overriding goal of the European Union, and the one that guides all these activities, is the idea of sustainable development contained in the treaty, which sets the direction and method of the pursuit of the set goal [19].

Institutions play a very important role in implementing sustainability in countries. The functioning of institutions in relation to sustainability depends on different factors. External crises and international pressure on institutions can trigger them to make progress towards sustainability [20]. The institutions can help transform economies toward sustainability and their proper functioning is very important. Institutional failure is not only negative for sustainability, but also creates destabilization [21].

Agriculture plays a very important supporting role, not only in providing food for society, but also energy for farms and local economies. Agriculture production also creates emissions, mainly from conventional farming. That is why it is important to support forms of sustainable agriculture such as organic farming. Climate change risks and increasing environmental pollution, in contrast with the increasing demand for food, require the development of a food system that is safe and incorporates the production and distribution of food [22]. The EU has introduced agri-environmental programs, with the aim of providing compensation for farms to increase their incomes, reduce pesticide emissions, protect the natural life of inhabitants, reduce poverty, and restore the landscape [23]. The EU is becoming a resource-efficient competitive and low-carbon economy. To achieve these goals, the seventh Environmental Action Programme (2004-2020) and Common Agricultural Policy (CAP) have been incorporated [24].

\subsection{Renewable Energy Sources in Sustainable Development Concept}

Sustainable energy development is a process of safe, sustainable, and effective energy provision for the purposes of sustainable development. Through legal acts relating to the energy sector, the energy policy of the European Union aims to implement an approach consistent with the principles of sustainable development, including through the development of technologies using renewable energy resources and the development of cogeneration of thermal energy and electricity. Obtaining and using energy in this way is an essential component of sustainable development. Many countries that choose this direction create a 
new concept of energy development and carefully evaluate their energy systems in terms of their ability and functionality with the goals of sustainable development [11].

Overcoming challenges and seizing the many opportunities in today's world provides access to energy. Energy is necessary for the performance of work, ensuring security, combating climate change, producing food, and efforts to increase national income. Sustainable energy is an opportunity for a better future, as it can transform human lives, entire economies, and even our planet.

Renewable energy sources play a special role in the processes of balancing development in relation to energy [11]. The shaping and implementation of a sustainable energy policy that ensures energy security for EU countries requires the cooperation of authorities of all countries that meet the requirements of ecological safety by increasing competitiveness and energy efficiency. Rational use of renewable energy sources (RES) is one of the essential elements of the sustainable development of the state. The degree of use of renewable energy sources depends on the availability of resources and the technology of their processing [25]. A breakthrough event for entering a new stage of development of renewable energy sources was the signing of the Kyoto Protocol at the end of 1997, which was followed by an international agreement on climate change and counteracting global warming [26].

"The main goal of the energy policy is to create conditions for the constant and sustainable development of the energy sector, ensuring the energy security of the state, meeting the energy needs of enterprises and farms households and reducing the impact of energy on the environment. Improving energy efficiency will remain the priority of the energy policy" [27].

The implementation of the idea of sustainable development involves a balance of three main areas, i.e., environmental protection, economic growth, and social development [11,28-31]. In achieving these goals, the EU's energy policy has three main goals:

(1) ensuring security in energy supplies;

(2) ensuring competitive prices for energy consumers by increasing competition in energy markets;

(3) reducing the negative impact of the energy system on the environment.

Achieving these goals requires:

- Conducting wider dialogue and cooperation with EU countries, including partner regions, in the field of combating climate change and securing energy supplies;

- Improving policy coordination and coherence, and supporting energy policy-building authorities in building energy policy;

- Supporting and eliminating energy poverty by including issues and making efforts to develop them [19];

- Developing distributed energy with the use of local energy sources.

Many authors indicate that the main factor in balancing the development of the energy sector is energy policy. Each year, energy efficiency increases and the prices of energy from renewable sources decrease. This should be conducive to the use of renewable energy sources, i.e., a process that is highlighted in almost all statements on sustainable energy development [11].

Renewable energy sources are also leading to the creation of innovations. The EU creates about $30 \%$ of the world's patents on energy sources. However, many enterprises face challenges to achieve sustainability targets; hence, innovations can help in establishing mechanisms to leverage sustainability [32-34].

\subsection{Policy of Renewable Energy Sources}

The policies for RES, including biofuels, are a very important driver to fulfill the demand for energy and food security. The demand for RES and biodiesel has increased as the result of established policies. The production of biodiesel in 2005-2015 increased $700 \%$ and is expected to rise by other $35 \%$ by $2025[35,36]$. Biodiesel is produced in the EU, 
whereas bioethanol is made in the United States of America (USA). Hence, proper policies for each country, including local, regional, and international possibilities and resources, should be established [37].

The EU has elaborated its emission standards and mandates. The global policy aims to promote production of RES, including biofuels. These policies help increase biodiversity, reduce unemployment, and achieve biofuel production standards [38].

The increase in the share of energy from renewable energy sources and the reduction in carbon dioxide emissions are caused by the legal obligations entered into by EU member states with the EU under Directive 2009/28/EC of the European Parliament and of the Council of 23 April 2009, and by achieving the desired share of renewable energy in the final gross energy consumption [39]. The development of the security of the energy supply requires further increases in renewable energy, which help to achieve the established targets [40].

The directive of the EU established the necessity to achieve $20 \%$ of RES in global energy use and 10\% of biofuels in total transport fuel consumption by 2020 [41,42].

In December 2008, the European Union adopted the climate and energy package (the so-called $3 \times 20 \%$ package), which sets out actions to be taken by 2020 . These activities are recorded in the following documents: Decision 2009/406/EC, Directive 2003/87/EC, Directive 2009/28/EC, Directive 2009/29/EC, and Regulation 443/200942. The assumption made was to reduce the annual greenhouse gas emissions by at least $20 \%$, and to reduce energy consumption by $20 \%$ in 2020 compared to 1990 (increase in energy efficiency by $20 \%$ ). The goal was then adopted to increase the share of energy from renewable sources in final energy consumption to $20 \%$ (each country in the European Union has set an individual target, e.g., Germany-18\% and Poland-15\%), and increasing the share of liquid biofuels to $10 \%$ in fuel consumption in transport [43].

In December 2018, the new Directive 2018/2001 elaborated the aim of delivering clean energy for European citizens. The EU should be the leader in delivering clean energy. According to the regulation, the EU should acquire at least $32 \%$ of its energy from renewable sources by 2030, and renewable sources should supply $14 \%$ of the energy in transport [44]. The Renewable Energy Directive (RED II) was completed with a legal framework as part of the directive recast by the EU in December 2018 [45].

The reduction of coal consumption in many countries creates changes in the energy sector because coal is the main source of heat for households. However, burning coal causes smog, which is the source of deaths [46]. The need to increase the consumption of RES has surpassed the demand for fossil fuels for the first time [47].

\section{Materials and Methods}

\subsection{Material}

The main source of material for the analysis was data obtained from Eurostat. This included yearly data, including the share of renewable energy sources in particular EU countries. The data covered the years 2004-2019. The 15 years of observations provide the changes in the share of renewable energy sources.

"Energy is said to be renewable when it's sourced from renewable resources such as the sun, wind, water, or biomass. Renewable energy does not use fossil fuels, coal, or gas, but rather natural resources that can be replenished within the human lifetime" [48].

Table 1 confirms the development of renewable energy that supports sustainable development. The concept of sustainable development is important in the EU. Various policies support the development, such as the Common Agricultural Policy (CAP). The concept refers not only to environmental problems and how to overcome them, but also to subsidies (green box subsidies) for social cohesion, capital, and inclusion [47].

Renewable energy sources are used in heating systems. The low-carbon economy depends on household decisions concerning residential heating systems. The household socio-economic characteristics have an impact on good decision making. [48,49]. Another decisive factor is policy decision making, which shapes social costs and fuel poverty. 
Fuel poverty is a challenge that requires investments in public housing renovation [50]. Households benefit from retrofitting. "Furthermore, the application of the developed framework can serve as an evidence base for retrofit designers, contractors, and policy makers in the design of retrofit packages and policy measures that will maximize the benefit for householders" [51].

Table 1. Shares of energy from renewable sources and their changes in the European Union in 2004-2020 (\%).

\begin{tabular}{|c|c|c|c|c|c|c|c|c|c|c|c|c|}
\hline Country & 2004 & 2010 & 2011 & 2012 & 2013 & 2014 & 2015 & 2016 & 2017 & 2018 & 2019 & 2020 \\
\hline Euro area-19 & 8.400 & 3.156 & 3.128 & 14.621 & 15.264 & 6.079 & 16.446 & 16.697 & 17.271 & 17.773 & 18.576 & 20.951 \\
\hline-27 countries & 9.633 & 1 & & & & & & & & & 730 & 0.089 \\
\hline European Union-28 countries & 8.559 & 3.161 & 3.389 & 14.663 & 15.370 & 6.203 & 6.734 & 16.982 & 17.482 & 8.012 & 8.877 & na \\
\hline Austria & 22.554 & .207 & .553 & 32.736 & 32.666 & 3.553 & 3.502 & 33.374 & 33.141 & 3.806 & 33.626 & 36.545 \\
\hline Belgium & 1.890 & 6.002 & 6.275 & 7.089 & 7.650 & 8.043 & 8.026 & 8.752 & 9.113 & 9.478 & 9.924 & 13.000 \\
\hline Bulgaria & 9.231 & 13.928 & 14.152 & 15.837 & 18.898 & 18.050 & 18.261 & 18.760 & 18.701 & 20.592 & 21.564 & 23.319 \\
\hline Croatia & 23.404 & 25.103 & 25.389 & 26.757 & 28.040 & 27.817 & 28.969 & 28.267 & 27.28 & 28.047 & 28.466 & 31.023 \\
\hline & 2071 & 6172 & 6261 & 7.137 & 8456 & 9.173 & & & & & 13.800 & 16.879 \\
\hline Cze & 6.774 & 10.514 & 10.945 & 12.813 & 13.927 & 15.073 & 15.067 & 14.924 & & & 16.244 & 303 \\
\hline & & & & & 27.174 & 29.323 & & & & & & 31.648 \\
\hline & 18.389 & 24.599 & 7 & 25.5 & 25.321 & 26.141 & & 28.715 & & 93 & 1.889 & 069 \\
\hline & 29.2 & & & & & & & & & & 081 & 802 \\
\hline & & 12670 & & & 13.908 & 14.422 & & & & & & \\
\hline & 6. & 7 & 12. & & 60 & 85 & & & & & 354 & 312 \\
\hline & & & & & & & & & & & 677 & 749 \\
\hline & 4.364 & 12.742 & 13.972 & 30 & 16.205 & 14.618 & 14 & 377 & & & 614 & 850 \\
\hline & & & & & & & & & & & & 160 \\
\hline & & 3 & & & 16. & 82 & & & & & & 359 \\
\hline & & & & & & & & & & & 775 & 132 \\
\hline & 17.223 & 19 & & & 90 & 594 & & & & & 5.461 & 26.773 \\
\hline $\mathrm{Lu}$ & 0.899 & & & & 3.499 & 4.469 & & & & & & 11.699 \\
\hline Mal & & & & & & & & & & & & 10.714 \\
\hline The & & & & & 4.691 & & & & & & & 13.999 \\
\hline & & & & & & & & & & & & 16.102 \\
\hline & 9 & & & & & & & & & & 19 & 33.982 \\
\hline & & & & & & & & & & & & 24.478 \\
\hline & & & & & & & & & & & & 345 \\
\hline & 3.397 & 0 & & & & & & & & & & 000 \\
\hline & & & & & & & & & & & & 21.220 \\
\hline & & & & & & & & & & & 391 & 60.124 \\
\hline United Kingdom & 1.096 & 3.862 & 4.392 & 4.461 & 5.524 & 6.737 & 8.385 & 9.032 & 9.858 & 11.138 & 12.336 & 13.421 \\
\hline
\end{tabular}

Source: own elaborations based on [52]. https:/ / ec.europa.eu/eurostat/databrowser/view/nrg_ind_ren/default/ table?lang=en (accessed on 18 January 2022). n.a.-not available.

The European Union is the best geographical scope of research because it is a common market. Countries belonging to the EU have common regulations concerning renewable energy sources. The share of energy from renewable sources is computed in three consumption sectors (electricity, heating and cooling, and transport) in the European Union (EU). Renewable energy sources include wind power, solar power (thermal, photovoltaic, and concentrated), hydro power, tidal power, geothermal energy, ambient heat captured by heat pumps, biofuels, and the renewable part of waste [52].

The biggest shares of renewable energy sources were observed in 2020 in Sweden $(60.1 \%)$, Finland $(43.8 \%)$, and Latvia $(42.1 \%)$ (Table 1$)$. The smallest shares of renewable energy sources were observed in 2020 in Malta (10.7\%), Belgium (13.0\%), and Hungary (13.8\%).

\subsection{Methods}

We tested whether the share of RES data is non-stationary and conducted the Augmented Dickey-Fuller test (ADF test) [53]. The ADF test is a unit root test used for checking non-stationarity [54]. Using the Augmented Dickey-Fuller test, we checked two hypotheses. The null (first) hypothesis says that the time series is a unit root. The alternative (second) hypothesis is that the time series is not stationary.

Next, we analyzed the time series using the Generalized Autoregressive Conditional Heteroscedasticity (GARCH) models, which were elaborated by Engle [55] and Boller- 
slev [56]. The models can describe the volatility clustering and unconditional return distribution [57], and are presented by the equation:

$$
\sigma^{2}{ }_{t}=\alpha_{0}+\alpha_{1} y^{2}{ }_{t-1}+\beta_{1} \sigma^{2}{ }_{t-1}
$$

In the GARCH notation, the first subscript refers to the order of the $y^{2}$ terms on the right-hand side, and the second subscript refers to the order of the $\sigma^{2}$ terms [51]. The Generalized Autoregressive Conditional Heteroscedasticity (GARCH) method is used to analyze conditional variance that is not stationary [57].

The share of RES is described as Autoregression $(\operatorname{AR}(p)$-Generalized Autoregressive Conditional Heteroscedasticity GARCH (1.1), given by:

$$
\begin{gathered}
y_{t}=\phi_{0}+\sum_{i=1}^{p} \phi_{i} y_{t-i}+e_{t}, \\
e_{t} \mid \psi_{t-1} \sim t\left(v, 0, h_{t}\right), \\
h_{t}=\alpha_{0}+\alpha_{1} e_{t-1}^{2}+\beta_{1} h_{t-1},
\end{gathered}
$$

where $\psi_{t-1}$ denotes the series history up to time $t-1, t\left(v, 0, h_{t}\right)$ is a Student's $t$ distribution with $v$ degrees of freedom $(v>2)$, and $h_{t}$ is the conditional variance. Given the regularity conditions, $\alpha_{0}>0, \alpha_{1} \geq 0, \beta_{1} \geq 0$, the required stationarity condition is $\alpha_{1}+\beta_{1}<1$. Moreover, due to the presence of autocorrelation, the roots of the polynomial $z^{p}-\phi_{1} z^{p-1}-\phi_{2} z^{p-2}-\ldots-\phi_{p}=0$ lie inside the unit circle. According to the GARCH models, the residual depends on a previous period's value and the variance [58]. The GARCH model can satisfactorily explain the volatility of the analyzed series [59].

\section{Results}

\subsection{Proportion of Use of Individual Energy Carriers in Europe}

Renewable energy sources (RES) are an alternative to traditional primary non-renewable energy sources such as fossil fuel. Obtaining energy from these sources is much less environmentally friendly than renewable sources. The use of renewable energy in the energy mix significantly reduces the harmful impact of the energy sector on the natural environment, mainly by reducing the emission of harmful substances, especially greenhouse gases [60].

In 2016, EU farms used 173 million ha. of land for agricultural production. Almost three-quarters of the EU's utilized agricultural area was located in just seven Member States: France, Spain, Great Britain, Germany, Poland, Italy, and Romania [61].

By contrast, forests in the EU cover 158 million ha and two-thirds of the EU's forest areas are in the six Member States having the largest forest areas; Sweden, Finland, Spain, France, Germany, and Poland [62].

Poland's high position compared to the EU in terms of the availability of agricultural and forestry areas is due to the use of solid biofuels in the structure of primary energy production, which account for $65.5 \%$ and exceed the EU average by $25 \%$. Moreover, the share of liquid biofuels is in Poland is $10.3 \%$, which is higher than the EU average of $6.8 \%$. By comparison, the use of wind energy in Poland is similar to the EU average, accounting for $13.7 \%$ and $13.9 \%$, respectively. Northern and Central Europe will increase their wind energy potential when that of Eastern Europe decreases. Although Europe is an important producer of wind energy, the north-south divide will not jeopardize its development [63-66]. The most important source of wind energy is onshore farms. The quantity of offshore wind energy produced in Europe will probably decrease [67].

The development of renewable energy is essential for the achievement of the basic goals of climate and energy policies. Increasing the use of renewable energy sources offers the opportunity to increase energy efficiency [60]. This applies to both the production of electricity and heat.

As part of the climate and energy policy until 2030, the most important goals of the EU for 2030 will be: an increase in the share of renewable energy in gross final energy 
consumption in the European Union countries to $32 \%$ (for Poland it is 23\%); and the reduction in greenhouse gas emissions by at least $40 \%$ (compared to the level from 1990) (for Poland it is 30\%) [7].

In recent decades, the development of renewable energy sources has become one of the most important goals of the energy policy of the European Union countries [68].

Poland, as a member of the European Union, actively participates in the creation of the Community's energy policy, and implements its main goals in specific national conditions. This takes into account the protection of consumers' interests, energy resources, and technological conditions of energy production and transmission [6], in addition to the need to reduce greenhouse gas emissions, in particular $\mathrm{CO}_{2}$, thus indicating the need to use renewable energy sources (RES) [69].

The increasing usage of renewable energy sources is attracting interest globally in urban and rural areas. Cities are elaborating strategies of sustainability with renewable energy sources to impact the environmental conditions in which we live. The strategies are based on environmentally friendly actions that include product management; preservation of nature, processes, and activities; preservation of wild animals, species, and plants; adjusting enterprises to social needs; and various actions to improve the quality of environment [70-73].

Figure 1 depicts the changes in renewable energy sources. The biggest increases in renewable energy sources were achieved in Malta (10,403.9\%) and Luxemburg (1201.3\%). It is worth mentioning that all countries of the EU increased their share of renewable energy sources. The smallest increases were observed in Latvia (28.5\%), Croatia 32.6\%), and Slovenia (35.9\%).

Poland is one of the few Member States of the European Union having a low value, reaching only $16.1 \%$. The average goal for the entire EU is $20 \%$ and this target was fully achieved, at $20.1 \%$, in 2020 .

Renewable energy sources are represented by biomass, photovoltaics, wind energy, water energy, biofuels, and other. However, stable biomass still has the biggest potential. Wood and straw are insufficient to cover the needs of stable biomass usage [74]. Hence, short rotation coppices and perennial herbaceous crops (PHC) are also used to meet demand for stable biomass. External lands of limited value and quality can be used for such plants [75]. To increase the production of stable biomass, suitable EU legislation supporting energy producers is needed. Germany is the biggest producer of wood pellets, which are the most important product used for heating. The potential of biomass production is increasing in Latvia, Lithuania, Estonia, and Sweden [76].

Another source of renewable energy is wind energy. The potential of wind is also increasing [77], although further investment is needed to increase the wind potential. The technology is expensive, but smaller energy losses and fewer turbine failures were observed [78]. Electricity derived from wind installation is clean and it has increased from $2.4 \%$ in 2000 to $10.2 \%$ by 2014 [79].

The global photovoltaic market has also grown. Germany is the leader in photovoltaics in Europe. About 4\% of the Union's electricity demand was met by solar PV in 2018. However, the ambitious goal to reach the 2030 target requires a larger investment [80].

Biofuels are also a very important source of RES in Europe. The production of biofuels is diversified in the EU. The highest average shares of biodiesel in the EU in 2004-2019 were in Germany (3788.2 thousand tonnes), Spain (3111.9 thousand tonnes), France (2049.3 thousand tonnes), the Netherlands (1379.1 thousand tonnes), and Poland (822.27 thousand tonnes). However, the biggest producers of biodiesel in the EU in 2019 were France, Poland, Germany, and Great Britain. The data reflect the development of biodiesel in the EU [81]. 


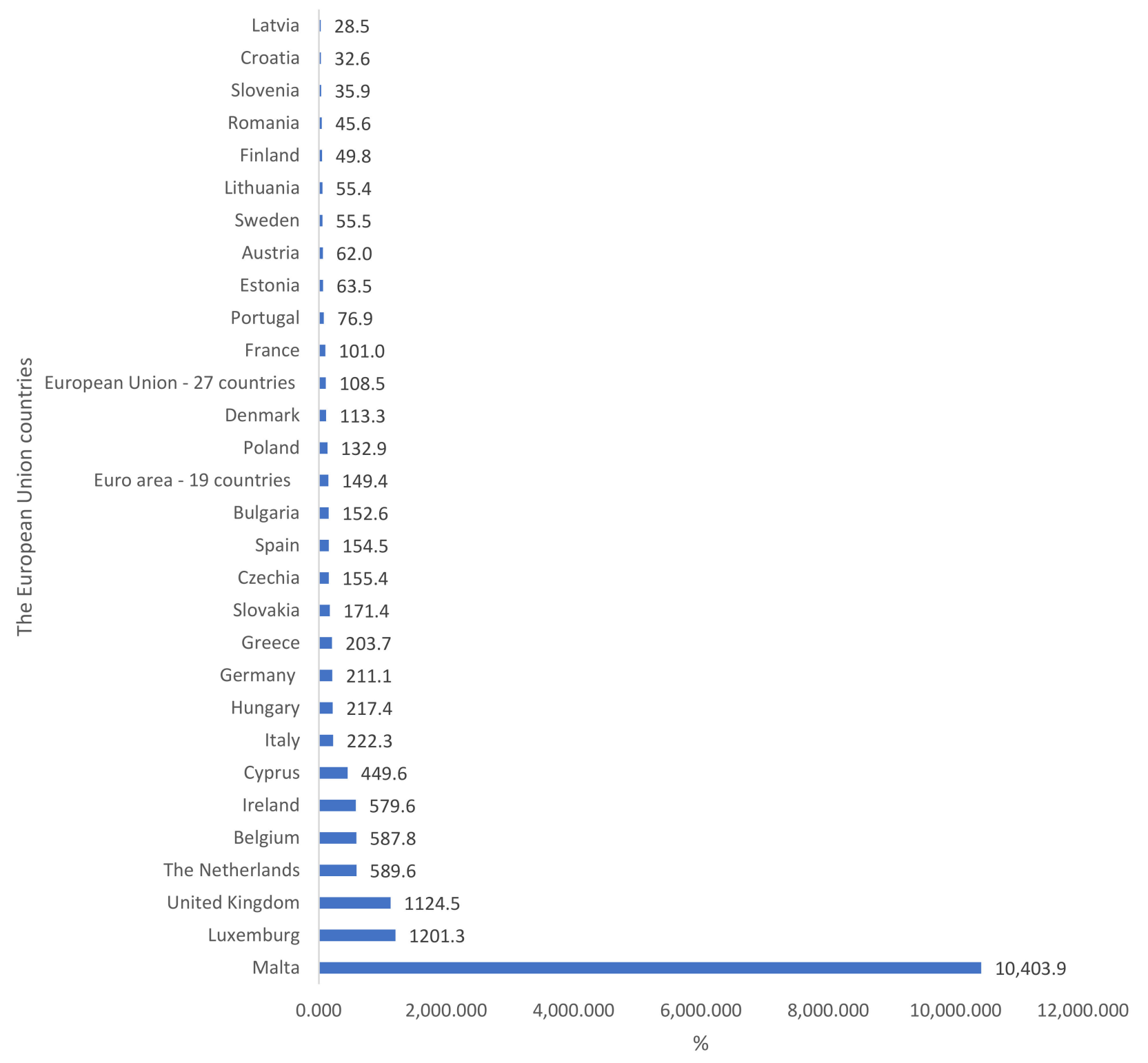

Figure 1. Changes in the share of energy from renewable source in the European Union in 2004-2020 (\%). Sources: own elaborations based on [52] https: / /ec.europa.eu/eurostat/databrowser/ view/nrg_ind_ren/default/table?lang=en (accessed on 18 January 2022).

Sweden (74.5\%), Portugal (58\%), and Croatia (53.8\%) achieved the highest shares of energy from renewable energy sources in gross electricity consumption in 2020 . These shares mostly result from the increase in wind and solar energy generation.

The biggest shares of energy from renewable energy sources for heating and cooling were achieved in 2020 in Sweden (66.4\%), Estonia (57.9\%), and Finland (957.6\%). The EU share increased from $11.7 \%$ in 2004 to $22.1 \%$ in 2019.

The share of energy from renewable energy sources in transport has also changed (Figure 2). The EU aimed to achieve a 10\% share of renewable energy sources in transport in 2020. Twelve countries achieved this share of renewable energy sources in transport, including Sweden (31.9\%), the Netherlands (12.6\%), and Luxemburg (12.6\%). Fifteen countries did not achieve the target, including Greece (5.3\%), Croatia (6.6\%), and Cyprus (7.4\%). 


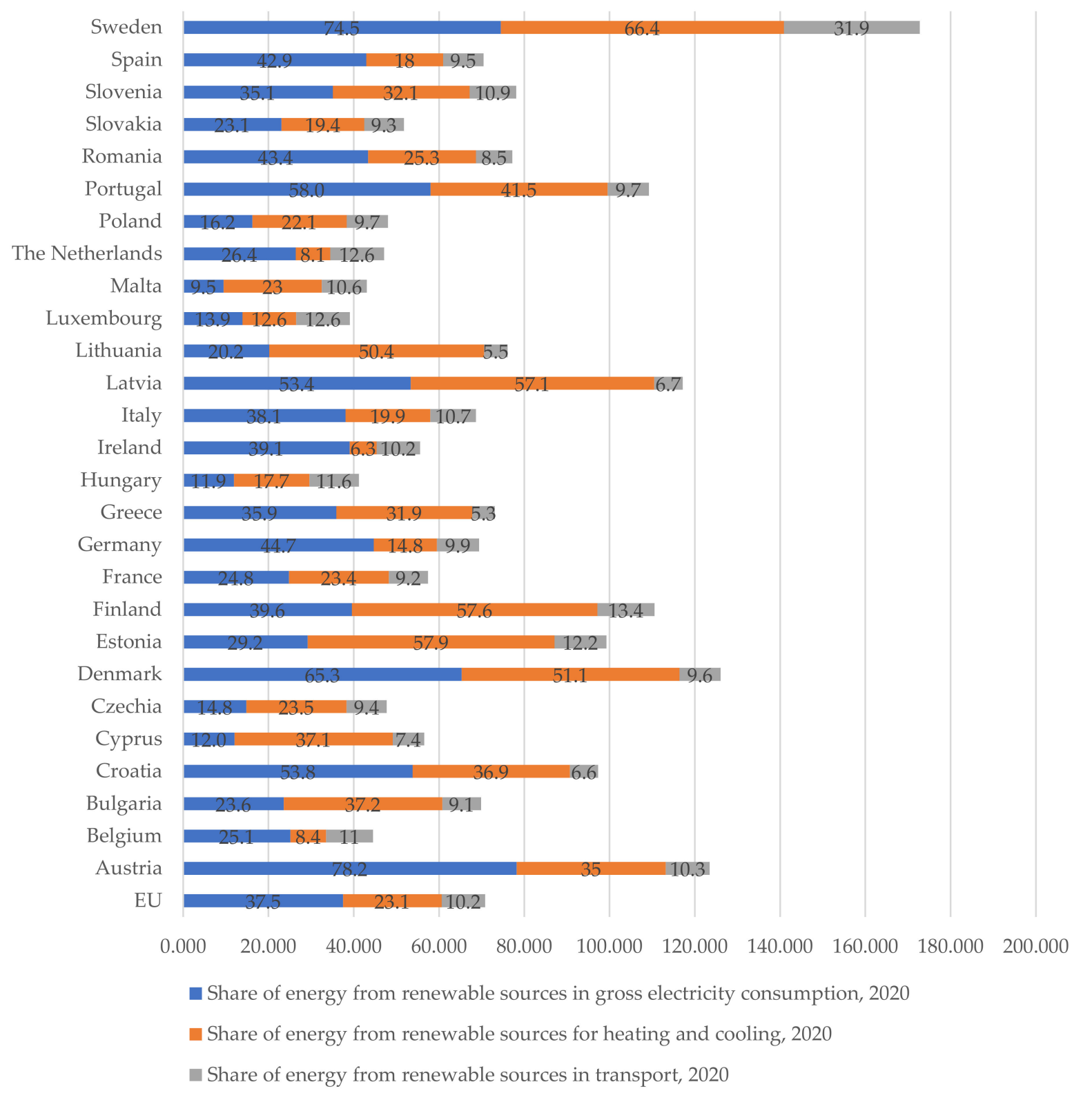

Figure 2. Share of energy from renewable sources in the European Union in 2020 (\%). Sources: own elaborations based on [52]. https:/ / ec.europa.eu/eurostat/databrowser/view/nrg_ind_ren/default/ table?lang=en (accessed on 18 January 2022).

Biodiesel is mostly made of rapeseed in Europe and is widely acceptable as a firstgeneration biofuel. It has specific characteristics, such as a lack of sulfur and a positive energy balance, and is economically competitive [82]. Moreover, biodiesel reduces greenhouse gas emissions and is biodegradable. However, the production of rapeseed requires good quality soils, and creates competition between food production and the petrochemical industry. Hence, second-(miscantus and willow) and third-(algae) generation biofuels should be promoted [83]. Despite the high prices of food stock, biodiesel is attracting increased attention worldwide [84].

In the future, biodiesel will replace diesel, which is considered to be the main contributor to environmental problems and the production of GHG (greenhouse gas) [85]. Biodiesel has almost zero emissions of sulfates, makes a small contribution to carbon dioxide $\left(\mathrm{CO}_{2}\right)$, and can replace diesel in combustion engines [86]. However, biodiesel is produced mainly 
from rapeseed in the EU. This situation creates additional competition for rapeseed between the nutrition and oil industries.

Renewable energy sources can be used in transport, heating and cooling, and other sectors. Transport is a crucial problem in the current economy because it is based on fossil fuels. Oil is mostly used as the main energy source in transport [87]. Transportation is creating demand for energy, which will increase by $60 \%$ in 2050 compared to 2015 [88]. The highest shares of renewable energy sources in transport in 2020 were observed in Sweden (31.9\%), Finland (13.4\%), and Slovenia (10.9\%) (Figure 2).

Heating and cooling are important aspects of human activity that use energy. Modern devices should use renewable energy sources in heating and cooling because this can improve the air quality and combat climate change [89]. In the European Union (EU), about $40 \%$ of total energy consumption is used by buildings. This share will increase because of population growth [90,91]. In the European Union (EU), the shares of energy from renewable energy sources were the highest in 2020 in Sweden (66.4\%), Lithuania (57.9\%), and Finland (57.6\%). The European Union (EU) is also using renewable energy sources in its gross electricity consumption. The highest uses in 2020 were in Austria (78.2\%), Sweden (74.5\%), and Portugal (58\%).

The highest average shares of renewable energy sources were found for the years 2004-2019 in Iceland, Norway, and Sweden (Table 2). The lowest shares of renewable energy sources were found for the years 2004-2019 in Luxemburg, the Netherlands, Belgium, and Ireland.

Table 2. Descriptive statistics of the share of energy from renewable sources in the European Union in 2004-2019.

\begin{tabular}{|c|c|c|c|c|c|c|c|c|}
\hline Country & Average & Median & Minimal & Maximal & $\begin{array}{c}\text { Standard } \\
\text { Deviation }\end{array}$ & $\begin{array}{l}\text { Coefficient } \\
\text { of Variation }\end{array}$ & Skewedness & Kurtosis \\
\hline Euro area-19 countries & 13.808 & 13.889 & 8.400 & 18.576 & 3.268 & 23.70 & -0.224 & -1.218 \\
\hline European Union -27 countries & 15.070 & 15.288 & 9.633 & 19.730 & 3.299 & 21.89 & -0.263 & -1.268 \\
\hline European Union-28 countries & 13.930 & 14.026 & 8.560 & 18.877 & 3.352 & 24.06 & -0.178 & -1.273 \\
\hline Austria & 30.645 & 32.109 & 22.554 & 33.806 & 3.585 & 11.70 & -1.082 & -0.108 \\
\hline Belgium & 6.163 & 6.682 & 1.890 & 9.924 & 2.758 & 44.76 & -0.253 & -1.389 \\
\hline Bulgaria & 14.876 & 14.994 & 9.098 & 21.564 & 4.499 & 30.20 & -0.077 & -1.511 \\
\hline Croatia & 25.728 & 26.073 & 21.986 & 28.969 & 2.499 & 9.71 & -0.210 & -1.534 \\
\hline Cyprus & 7.482 & 6.699 & 3.071 & 13.898 & 3.514 & 46.96 & 0.431 & -0.813 \\
\hline Czechia & 11.703 & 11.879 & 6.774 & 16.244 & 3.406 & 29.10 & -0.178 & -1.349 \\
\hline Denmark & 25.052 & 24.428 & 14.840 & 37.704 & 7.532 & 30.65 & 0.179 & -1.349 \\
\hline Estonia & 24.105 & 25.334 & 15.972 & 31.889 & 5.132 & 21.29 & -0.270 & -1.241 \\
\hline Finland & 34.899 & 33.502 & 28.814 & 43.081 & 4.883 & 13.99 & 0.254 & -1.443 \\
\hline France & 12.947 & 19.973 & 9.337 & 17.216 & 2.634 & 20.34 & 0.054 & -1.318 \\
\hline Germany & 12.369 & 12.988 & 6.207 & 17.354 & 3.336 & 26.97 & -0.342 & -0.918 \\
\hline Greece & 12.47 & 14.447 & 7.160 & 19.677 & 4.346 & 34.92 & 0.134 & -1.481 \\
\hline Hungary & 11.761 & 12.678 & 4.364 & 16.205 & 3.502 & 29.78 & -0.709 & -0.686 \\
\hline Ireland & 6.755 & 6.788 & 2.378 & 11.984 & 3.086 & 45.68 & 0.101 & -1.223 \\
\hline Italy & 13.789 & 14.232 & 6.318 & 18.267 & 4.107 & 29.78 & -0.493 & -1.148 \\
\hline Latvia & 34.992 & 35.014 & 29.615 & 40.975 & 3.771 & 10.780 & 1.210 & -1.387 \\
\hline Lithuania & 21.241 & 20.691 & 16.482 & 26.039 & 3.611 & 17.00 & 0.036 & -1.543 \\
\hline Luxembourg & 3.849 & 3.022 & 0.899 & 8.973 & 2.193 & 56.98 & 0.821 & 0.014 \\
\hline Malta & 3.135 & 2.356 & 0.102 & 8.488 & 3.104 & 98.99 & 0.473 & -1.276 \\
\hline The Netherlands & 4.730 & 4.592 & 2.030 & 8.768 & 1.808 & 38.22 & 0.553 & -0.184 \\
\hline Poland & 9.737 & 10.662 & 6.889 & 12.164 & 2.065 & 21.21 & -0.386 & -1.537 \\
\hline Portugal & 25.636 & 24.593 & 19.209 & 30.868 & 4.210 & 16.42 & -0.023 & -1.389 \\
\hline Romania & 21.787 & 22.829 & 16.811 & 25.032 & 2.993 & 13.64 & -0.031 & -1.135 \\
\hline Slovakia & 10.069 & 10.241 & 6.360 & 16.894 & 2.808 & 27.88 & 0.596 & 0.261 \\
\hline Slovenia & 20.922 & 21.229 & 18.397 & 23.161 & 1.533 & 7.33 & -0.413 & -0.950 \\
\hline Spain & 13.705 & 14.072 & 8.339 & 18.362 & 3.493 & 25.49 & -0.304 & -1.312 \\
\hline Sweden & 48.446 & 49.081 & 38.677 & 56.391 & 5.458 & 11.27 & -0.318 & -1.090 \\
\hline United Kingdom & 5.474 & 4.427 & 1.096 & 12.336 & 3.685 & 67.32 & 0.487 & -1.053 \\
\hline
\end{tabular}

Source: own elaborations based on [52]. https:/ / ec.europa.eu/eurostat/databrowser/view/nrg_ind_ren/default/ table?lang=en (accessed on 18 January 2022).

The highest minimal shares of renewable energy sources for the years 2004-2019 were observed in Iceland, Norway, and Sweden. The lowest minimal shares of renewable energy sources were observed in Malta, Luxemburg, and Belgium. 
The coefficients of variation were the highest during 2004-2019 in Malta, United Kingdom, and Cyprus. The lowest coefficients of variation were observed in Slovenia, Iceland, and Norway.

The highest maximal shares of renewable energy sources in the years 2004-2019 were found in Iceland, Norway, and Latvia. The lowest were found in Luxemburg, the Netherlands, and Malta.

Kurtosis was negative in many countries of Europe, except Luxemburg and Slovakia. Skewedness was also negative in most countries of Europe, except Denmark, Iceland, Greece, France, Cyprus, Latvia, Lithuania, Luxemburg, Malta, the Netherlands, Slovakia, Finland, Norway, and Great Britain.

\subsection{Evaluation of Stationarity of Renewable Energy Sources in the EU}

The Augmented Dickey-Fuller test was used to examine the stationarity of the share of renewable energy sources. When the time series is stationary it has a finite mean. Moreover, the data fluctuate around a constant long-run mean. A stationary series is described by a finite variance [59].

We tested the null hypothesis that the time series has a unit root and is not stationary (Table 3). According to Stewart and Blayney [92] "the test is applied to a variable and then to its differences until a stationary series is identified". The highest $p$-values were observed in the Netherlands, Denmark, and Cyprus. These high $p$-values indicate the time series are not stationary; hence, we calculated the first difference.

Table 3. Augmented Dickey-Fuller test (ADF test) results of the share of renewable energy sources in the European Union.

\begin{tabular}{|c|c|c|c|c|}
\hline \multirow[t]{2}{*}{ Country } & \multicolumn{2}{|c|}{$p$-Value } & \multicolumn{2}{|c|}{$p$-Value (First Differences) } \\
\hline & Without Trend & With Trend & Without Trend & With Trend \\
\hline European Union-27 countries & 0.650 & 0.832 & 0.013 & 0.026 \\
\hline European Union- 28 countries & 0.786 & 0.754 & 0.016 & 0.044 \\
\hline Euro area-19 countries & 0.716 & 0.623 & 0.005 & 0.013 \\
\hline Belgium & 0.762 & 0.902 & 0.050 & 0.133 \\
\hline Bulgaria & 0.938 & 0.425 & 0.019 & 0.084 \\
\hline Czechia & 0.845 & 0.359 & 0.182 & 0.435 \\
\hline Denmark & 0.998 & 0.299 & 0.162 & 0.014 \\
\hline Germany & 0.421 & 0.369 & 0.029 & 0.067 \\
\hline Estonia & 0.838 & 0.033 & 0.125 & 0.353 \\
\hline Ireland & 0.997 & 0.122 & 0.002 & 0.006 \\
\hline Greece & 0.985 & 0.307 & 0.097 & 0.249 \\
\hline Spain & 0.787 & 0.663 & 0.004 & 0.007 \\
\hline France & 0.916 & 0.008 & 0.000 & 0.010 \\
\hline Croatia & 0.855 & 0.348 & 0.079 & 0.246 \\
\hline Italy & 0.212 & 0.935 & 0.054 & 0.022 \\
\hline Cyprus & 0.982 & 0.096 & 0.000 & 0.000 \\
\hline Latvia & 0.867 & 0.136 & 0.062 & 0.008 \\
\hline Lithuania & 0.879 & 0.492 & 0.025 & 0.097 \\
\hline Luxembourg & 0.996 & 0.326 & 0.002 & 0.008 \\
\hline Hungary & 0.074 & 0.952 & 0.066 & 0.047 \\
\hline Malta & 0.954 & 0.322 & 0.359 & 0.679 \\
\hline The Netherlands & 0.998 & 0.994 & 0.134 & 0.176 \\
\hline Austria & 0.101 & 0.333 & 0.454 & 0.002 \\
\hline Poland & 0.673 & 0.287 & 0.333 & 0.629 \\
\hline Portugal & 0.718 & 0.159 & 0.094 & 0.228 \\
\hline Romania & 0.439 & 0.892 & 0.055 & 0.013 \\
\hline Slovenia & 0.717 & 0.436 & 0.000 & 0.000 \\
\hline Slovakia & 0.986 & 0.008 & 0.073 & 0.430 \\
\hline Finland & 0.987 & 0.278 & 0.004 & 0.014 \\
\hline Sweden & 0.218 & 0.698 & 0.000 & 0.000 \\
\hline United Kingdom & 0.999 & 0.887 & 0.172 & 0.118 \\
\hline
\end{tabular}

The ADF test with first differences achieved lower $p$-values, showing that the null hypothesis was not rejected, and the Augmented Dickey-Fuller test confirmed that the series are stationary and integrated [53]. 
Table 4 presents the maximum-likelihood estimates for the GARCH model. This model has been widely used in the international literature, mainly to analyze financial and economic time series [93]. It is used to model the dynamic nature of volatility by specifying the conditional mean and variance [94].

Table 4. Generalized Autoregressive Conditional Heteroscedasticity (GARCH) model of the share of energy from renewable sources in 2004-2019 in the European Union.

\begin{tabular}{|c|c|c|c|c|c|c|c|c|}
\hline \multirow{2}{*}{ Country } & \multicolumn{4}{|c|}{ Alpha $(\alpha 1)$} & \multicolumn{4}{|c|}{ Beta $(\beta 1)$} \\
\hline & Coefficient & Std. Error & $\mathbf{z}$ & $p$ Value & Coefficient & Std. Error & $\mathbf{z}$ & $p$ Value \\
\hline European Union-27 countries & n.a. & n.a. & n.a. & n.a. & n.a. & n.a. & n.a. & n.a. \\
\hline European Union-28 countries & n.a. & n.a. & n.a. & n.a. & n.a. & n.a. & n.a. & n.a. \\
\hline Euro area -19 countries & 0.579 & 0.555 & 1.707 & 0.088 & 0.001 & 0.539 & 0.00 & 1.00 \\
\hline Belgium & 0.975 & 0.500 & 1.950 & 0.051 & 0.007 & 0.293 & 0.002 & 1.000 \\
\hline Bulgaria & 0.943 & 0.989 & 0.953 & 0.340 & 0.004 & 1.032 & 0.004 & 1.000 \\
\hline Czechia & 0.922 & 0.888 & 1.039 & 0.299 & 0.006 & 0.928 & 0.006 & 1.000 \\
\hline Denmark & 0.995 & 0.837 & 1.135 & 0.256 & 0.005 & 0.862 & 0.005 & 0.995 \\
\hline Germany & 0.875 & 0.804 & 1.088 & 0.277 & 0.001 & 0.967 & 0.001 & 1.000 \\
\hline Estonia & 0.910 & 1.459 & 0.625 & 0.532 & 0.000 & 1.513 & 0.000 & 1.000 \\
\hline Ireland & 0.875 & 0.585 & 1.494 & 0.135 & 0.000 & 0.572 & 0.000 & 1.000 \\
\hline Greece & 0.969 & 0.842 & 1.151 & 0.249 & 0.007 & 0.821 & 0.000 & 1.000 \\
\hline Spain & 0.805 & 1.132 & 0.711 & 0.477 & 0.003 & 1.492 & 0.002 & 1.000 \\
\hline France & 0.931 & 1.373 & 0.678 & 0.498 & 0.022 & 1.513 & 0.015 & 0.988 \\
\hline Croatia & 0.951 & 3.598 & 0.264 & 0.791 & 0.002 & 3.612 & 0.006 & 1.000 \\
\hline Italy & 0.859 & 0.695 & 1.237 & 0.216 & 0.004 & 0.761 & 0.006 & 1.000 \\
\hline Cyprus & 0.946 & 0.677 & 1.398 & 0.162 & 0.001 & 0.592 & 0.002 & 1.000 \\
\hline Latvia & 0.782 & 2.723 & 0.287 & 0.774 & 0.150 & 3.409 & 0.004 & 0.965 \\
\hline Lithuania & 0.944 & 2.151 & 0.439 & 0.661 & 0.009 & 2.293 & 0.004 & 1.000 \\
\hline Luxembourg & 0.994 & 0.509 & 1.953 & 0.051 & 0.001 & 0.258 & 0.003 & 1.000 \\
\hline Hungary & 0.791 & 0.592 & 1.335 & 0.182 & 0.009 & 0.731 & 0.013 & 0.990 \\
\hline Malta & n.a. & n.a. & n.a. & n.a. & n.a. & n.a. & n.a. & n.a. \\
\hline The Netherlands & 0.989 & 0.644 & 1.538 & 0.124 & 0.010 & 0.566 & 0.018 & 0.986 \\
\hline Austria & 0.827 & 1.350 & 0.693 & 0.523 & 0.005 & 1.554 & 0.004 & 1.000 \\
\hline Poland & 0.863 & 1.350 & 0.693 & 0.523 & 0.005 & 1.554 & 0.004 & 1.000 \\
\hline Portugal & 0.894 & 1.897 & 0.472 & 0.637 & 0.006 & 2.266 & 0.003 & 1.000 \\
\hline Romania & 0.843 & 1.798 & 0.469 & 0.634 & 0.006 & 2.035 & 0.603 & 1.000 \\
\hline Slovenia & 0.559 & 2.682 & 0.213 & 0.831 & 0.279 & 3.163 & 0.088 & 0.929 \\
\hline Slovakia & 0.989 & 1.224 & 0.809 & 0.419 & 0.010 & 1.271 & 0.008 & 0.994 \\
\hline Finland & 0.365 & 1.102 & 0.331 & 0.741 & 0.635 & 1.664 & 0.382 & 0.703 \\
\hline Sweden & 0.904 & 2.449 & 0.369 & 0.712 & 0.006 & 3.092 & 0.002 & 0.998 \\
\hline United Kingdom & 0.999 & 0.427 & 2.342 & 0.019 & 0.001 & 0.139 & 0.007 & 1.000 \\
\hline
\end{tabular}

Source: own elaborations based on [52]. https:/ / ec.europa.eu/eurostat/databrowser/view/nrg_ind_ren/default/ table?lang=en (accessed on 18 January 2022). n.a.-not available.

The empirical evidence suggests that there is no serial correlation for the analyzed series. For most countries $\alpha 1>\beta 1$, which means that the conditional variance depends more on information about the volatility observed in the previous period. Only for Finland is $\alpha 1<\beta 1$, which suggests that the conditional variance is independent from previous prices.

\section{Discussion}

Renewable energy sources are now being gradually used and introduced in the European Union countries. This has a positive effect not only on the protection of the natural environment, but also on sustainable development.

On average, the EU has decreased $\mathrm{CO}_{2}$ emissions by $20 \%$ since 1990 . By comparison, Germany reduced its emissions by 30\%, the Czech Republic by 35\%, Hungary by 32\%, the other Baltic states by more than half, and Poland by $13 \%$. There are also countries in which greenhouse gas emissions have increased over three decades, e.g., Cyprus $+54 \%$, Spain $+20 \%$, and Portugal $+19 \%$ [95]. 
Irregularity in the operation of RES systems causes a significant gap between the average and maximum power, which is not observed in the case of system power plants, e.g., coal, nuclear, or gas. In order to cover the gap in power generation in the event of wind or sun failure, the country must maintain sufficiently large operational power reserves - both rotating and standing [96]. Apart from wind and solar energy, an especially important renewable energy source is agricultural and forest biomass. The reason for this is the universality and availability of this raw material [97]. In addition, biomass is a solid and more stable fuel, and is not dependent on the weather, like solar or wind energy.

The growing interest in renewable energy sources is caused by greater public awareness of climate change and environmental protection, in addition to programs introduced by governments, e.g., "my electricity" and "clean air", or municipal grants from European funds for the construction of, among other facilities, photovoltaic installations.

Many countries of the EU have high energy consumption linked to their economies, low electricity consumption, low environmental and energy awareness, and high usage of coal. Therefore, some solutions differ greatly from the aims of sustainable development. One wonders whether our internal security is supported by the concept of sustainable energy used in Europe. The necessity for extensive and costly systemic changes may affect the economic and existential stability of the inhabitants of Poland [12]. Today, development of renewable energy sources is needed. Poland belongs to the EU, within which all countries have to increase their share of renewable energy sources. The whole of the EU is required to increase its renewable energy share to $65 \%$ by 2050 . The development of new businesses in the renewable energy sector depends on costs, which have increased due to the COVID-19 crisis. However, the generation of energy from wind farms and photovoltaics, not only inland but also offshore, will reduce these costs [98,99].

Not all countries can create favorable economic conditions and social awareness. Countries such as Norway and Denmark can shape the energy system based almost exclusively on non-renewable sources, as they have favorable conditions for this. However, for Poland and many other countries, this solution is currently too costly and dangerous. It is difficult to fairly compare countries in terms of energy sustainability because their economic systems were shaped in different realities. The postulate of abandoning non-renewable sources creates favorable prospects for the environment, but also exposes an entire economy to losses related to the problems of rising energy prices, reducing competitiveness in international markets, and increasing instability of the energy transmission system (especially electricity) [95].

It is particularly important to be aware that it is not always possible to operate large power plants using renewable sources, and this is common with the use of non-renewable resources. Therefore, it seems reasonable to conclude that, in some regions of the world, sustainable energy may evolve based on non-renewable sources. With the help of the dominant role of local communities, it is possible to use the locally available renewable energy resources [95], such as biomass or agricultural biogas, to a limited extent.

Each year, there is a significant increase in the global use of renewable energy sources in the energy system. The EU Member States are faced with the need to build competitive internal energy markets and to respond to global problems resulting from climate change [96]. The EU energy policy and the applicable legal acts relating to the power sector are aimed at the implementation of the philosophy consistent with the principles of sustainable development [19]. It should be emphasized that Poland is only bound by the goal to be achieved. Each country will individually determine how this goal will be achieved, both in terms of reducing $\mathrm{CO}_{2}$ emissions [97] and meeting the requirements for obtaining the set limits on gross energy production from renewable sources. Compared to other EU countries, Poland is distinguished by a significant advantage in the use of solid biofuels (biomass), which exceeds the EU average by $25 \%$ within the structure of obtaining primary energy from renewable sources. In addition to the implementation of energy policy objectives required by EU Member States, investment and modernization 
measures are also required, especially in the field of energy infrastructure [96]. In Poland, these modernization activities should also take place in the structure of heating systems.

With the available resources of agricultural and forest land, it seems fully justified to create small power plants and heating plants adapted to biomass combustion in a distributed system. These plants can use the local resource base in a cogeneration system, where, in addition to electricity production, local heat is used [97]. This idea is based on previous analysis of the quantity of available raw materials provided by agriculture, where it is first necessary to meet the food needs of the country, and only then produce liquid fuels and solid fuels for energy purposes [100,101]. It is particularly important to broadly develop combined technologies for generating electricity and heat, as this is an effective way to achieve primary energy savings, reduce $\mathrm{CO}_{2}$ emissions, and reduce energy production costs [97], initially through the development of technologies that use renewable energy resources [11].

Germany (31,260 MW), Spain (18,602 MW), United Kingdom (7894 MW), and France (6108 MW) had the highest average wind cumulative installed capacities in 2004-2017 [102,103]. Many farms now exist onshore and offshore.

The renewable energy deployment by source and application in 2030 will change compared to the current state. In $2030,45 \%$ of energy consumption is expected to come from renewable power generation (onshore and offshore wind, hydropower, biofuel power, solar power), $42 \%$ will be used for heating and cooling (biomass industry, biomass building, biomass and other renewables), and 13\% will be used for transport (transport biofuels). The structure of the future renewable energy mix is an opportunity for various enterprises, farms, and stakeholders to increase their business in acquiring clean energy [104].

The most important policy is the EU energy policy, which aims to improve the energy efficiency by at least $32.5 \%$ in 2030 compared to 2010 [105].

\section{Conclusions}

The European Union is one of the biggest renewable energy producers in the world. Due to need to reduce the emissions of $\mathrm{CO}_{2}$, it is necessary to increase the use of renewable energy sources.

Despite the increase in the share of renewable energy in the European energy mix, the Federal Republic of Germany is ranked first, having emissions exceeding 850 million tonnes of $\mathrm{CO}_{2}$ equivalent in 2018, followed by France (445 million tonnes), and Italy (428 million tonnes). Poland is currently the fourth largest emitter of greenhouse gases in the European Union. However, when converting this share to a per capita basis, Poland is ranked first, having 10.87 tonnes in greenhouse gas emissions, followed by Germany (10.34 tonnes) and Spain (7.12 tonnes). By comparison, the EU average is 8.42 tonnes of $\mathrm{CO}_{2}$ per capita.

The aim of the article was to present the development of the energy renewable sector in the Europe in relation to sustainable development. The EU has increased the share of renewable energy sources. Iceland, Norway, and Sweden are the countries with the highest average shares of renewable energy sources in the years 2004-2019. Luxemburg, the Netherlands, Belgium, and Ireland achieved the lowest shares of renewable energy sources in the years 2004-2019.

The analyzed data proved that the shares of renewable energy sources are not stationary. This means that the values of the numbers do not depend on previous values. These results demonstrate that the changes are mostly the results of elaborated targets, rather than the behavior of particular markets.

The policies of renewable energy sources should include national possibilities in achieving the elaborated targets. Most of the energy from renewable energy sources is derived from stable biomass. However, its share is decreasing and the share of photovoltaics and other carriers is increasing.

Renewable energy sources increase the sustainable development of an economy. The cleaner energy achieved from renewable energy sources compared to energy from fossil 
fuels helps to achieve environmental goals. The development of sustainable development in accordance with the increase in renewable energy has a positive impact on the creation of new workplaces in photovoltaics and other industries.

To achieve sustainable development, the EU energy policy should help develop energy businesses. This will include support for the private sector development of onshore and offshore wind and solar energy. This should be particularly supported in the EU countries with access to the sea. Countries lacking access to the sea should develop solid biomass businesses. However, the share of biomass in renewable energy is decreasing.

The development of renewable energy sources will be led mainly by the development of solar energy and photovoltaics. The EU increased its photovoltaics capacity from 11.36 to 134 GWp in the years 2008-2019 [106]. Poland (800 MWp), Belgium, France, Hungary, and Italy (more than $500 \mathrm{MWp}$ each) increased their capacity of PV power in 2019 compared to 2018 [89]. This energy is considered to be the cleanest energy, and can be produced in organic and inorganic semiconductors [107]. There are three generations of photovoltaics, for example, silicon wafers (first generation), thin films (second generation) [108], and organic low-cost solar-powered products (third generation) [109]. All of the discussed changes in renewable energy sources will lead to a reduction in greenhouse gas (GHG) emissions in 2030 by $40 \%$ compared to 1990 [110].

Author Contributions: Conceptualization, P.B., R.W. and A.B.-B.; methodology, P.B. and A.B.-B.; software, A.B.-B., P.B. and T.R.; validation, P.B., A.B.-B., R.W., T.R., B.K., B.M. and J.W.D.; formal analysis, P.B. and A.B.-B.; investigation, P.B. and A.B.-B.; resources, P.B. and A.B.-B.; data curation, P.B. and A.B.-B.; writing-original draft preparation, P.B., R.W., A.B.-B., B.K., B.M., T.R. and J.W.D.; writing-review and editing, P.B., A.B.-B. and J.W.D.; visualization, P.B., A.B.-B., R.W. and J.W.D.; supervision, P.B., A.B.-B., R.W. and J.W.D.; project administration, P.B. and A.B.-B., funding acquisition, P.B. and A.B.-B. All authors have read and agreed to the published version of the manuscript.

Funding: The results presented in this paper were obtained as part of a comprehensive study financed by the University of Warmia and Mazury in Olsztyn, Faculty of Agriculture and Forestry, Department of Agrotechnology and Agribusiness, grant number 20.610.012-110.

Institutional Review Board Statement: Not applicable.

Informed Consent Statement: Not applicable.

Data Availability Statement: Not applicable.

Conflicts of Interest: The authors declare no conflict of interest.

\section{Nomenclature}

$\begin{array}{ll}\text { ADF } & \text { Augmented Dickey-Fuller Test } \\ \text { EU } & \text { European Union } \\ \text { GARCH } & \text { model Generalized Autoregressive Conditional Heteroscedasticity model } \\ \text { RES } & \text { Renewable Energy Sources } \\ \text { CAP } & \text { Common Agricultural Policy } \\ \text { PHC } & \text { Perennial herbaceous crops } \\ \mathrm{CO}_{2} & \text { Carbon dioxide } \\ \text { GHG } & \text { Greenhouse gas }\end{array}$

\section{References}

1. Gebremariam, S.N.; Marchetti, J. Economics of biodiesel production: Review. Energy Convers. Manag. 2018, 168, 74-84. [CrossRef]

2. EIA. International Energy Outlook 2019, with Projections to 2040; Development of Energy, U.S. Energy Information Administration: Washington, DC, USA, 2019.

3. Tolmac, D.; Prulovic, S.; Lambic, M.; Radovanovic, L.; Tolmac, J. Global Trends on Production and Utilization of Biodiesel. Energy Sources Part B Econ. Plan. Policy 2013, 9, 130-139. [CrossRef]

4. Solaun, K.; Cerdá, E. Climate change impacts on renewable energy generation. A review of quantitative projections. Renew. Sustain. Energy Rev. 2019, 116, 109415. [CrossRef] 
5. IRENA. Global Energy Transformation. A Roadmap to 2050; International Renewable Energy Agency: AbuDbabi, United Arab Emirates, 2018.

6. Announcement of the Minister of Economy and Work of 1 July 2005. Obwieszczenie Ministra Gospodarki i Pracy z Dnia 1 Lipca 2005 r). Available online: https:/ / eli.gov.pl/eli/MP/2005/562/ogl (accessed on 18 January 2022).

7. Poland's Energy Policy until 2040-2019. Polityka Energetyczna Polski do 2040 r. 2019, pp. 77-79. Available online: https: / / www.gov.pl/web / klimat/polityka-energetyczna-polski (accessed on 18 January 2022). (In Polish)

8. Announcement of the Minister of Economy of 21 December 2009. Obwieszczenie Ministra Gospodarki z Dnia 21 Grudnia 2009 r. w Sprawie Polityki Energetycznej Państwa do 2030 r. Available online: https:/ / sip.lex.pl/akty-prawne/mp-monitor-polski/ polityka-energetyczna-panstwa-do-2030-r-17589536 (accessed on 18 January 2022). (In Polish)

9. Czapiewska, G. Kreowanie rozwoju zrównoważonego obszarów wiejskich w oparciu o biogazownie rolnicze. Zesz. Nauk. Wydziału Nauk. Ekon. Politech. Koszalińskiej 2014, 18, 11-25. (In Polish)

10. Romaniuk, W.; Łukaszuk, M.; Karbowy, A. Potencjalne możliwości rozwoju biogazowni w gospodarstwach rolnych w Polsce. Problemy Inżynierii Rolniczej. Probl. Inżynierii Rol. 2010, 18, 129-139. (In Polish)

11. Graczyk, A. Wskaźnik zrównoważonego rozwoju energetyki. Optimus. Studia Ekon. 2017, 4, 2017. (In Polish) [CrossRef]

12. Adamkiewicz, J. Zarys Koncepcji Zrównoważonego Bezpieczeństwa Energetycznego. Zesz. Naukowe. Organ. I Zarzadzanie/Politech. Śląska 2017, 104, 103-114. (In Polish) [CrossRef]

13. Dobson, A. Environmental sustainabilities: An analysis a typology. Environ. Politics 1996, 5, 401-428. [CrossRef]

14. Gostomczyk, W. Udział biomasy energetycznej w realizacji idei zrównoważonego rozwoju. Politech. Koszalińska 2013, 152, 384-385. (In Polish)

15. Czech, A. Uwarunkowania Polskiej Polityki Energetycznej w Kontekście Postulatu Zrównoważonego Rozwoju; Uniwersytet Ekonomiczny w Katowicach: Katowice, Poland, 2016; pp. 269-2016, ISSN 2083-8611. (In Polish)

16. Latoszek, E. Koncepcja zrównoważonego rozwoju w teorii i praktyce ONZ. Zrównoważony Rozwój a Globalne Dobra Publiczne w Teorii i Praktyce Organizacji Międzynarodowych; Dom Wydawniczy Elipsa: Warszawa, Poland, 2016. (In Polish)

17. Jasiulewicz, M.; Janiszewska, D.A. Produkcja żywnościowa i energetyczna w kontekście zrównoważonego rozwoju Rolnictwa Polski. Politech. Koszalińska 2013, 152, 370-381. (In Polish)

18. Journal of Laws 94.49.196, as Amended, Art. 3.3 A. Dz. U. 94.49.196, z Późn. Zm., Art. 3.3 A. Available online: https: / / sip.lex.pl/akty-prawne/dzu-dziennik-ustaw/ochrona-i-ksztaltowanie-srodowiska-16790485 (accessed on 18 January 2022).

19. Graczyk, A. Energetyka jako czynnik równoważenia rozwoju obszarów wiejskich w Polsce do roku 2020. Zrównoważony Rozw. Obsz. Wiej. Asp. Ekol. Szczec Wydaw. Econ. 2010, 102-120. Available online: https://wneiz.pl/katedry/kpsg/publikacje/ zrownowazony_rozwoj_obszarow_wiejskich_t2.pdf\#page=102 (accessed on 18 January 2022). (In Polish).

20. Gunderson, L.H.; Holling, C.S. (Eds.) Panarchy: Understanding Transformations in Human and Natural Systems; Island Press: Washington, DC, USA, 2002.

21. Bauer, M.W.; Knill, C. A conceptual framework for the comparative analysis of policy change: Management, explanation and strategies of policy dismanting. J. Comp. Policy Anal. Res. Pract. 2014, 16, 28-44. [CrossRef]

22. Nasalski, Z. Determinants of agricultural farm participation in regional economic systems. Entrep. Sustain. Issues 2021, 9, 374-384. [CrossRef]

23. Czyżewski, B.; Trojanek, R.; Dzikuć, M.; Czyżewski, A. Cost-effectiveness of the common agricultural policy and environmental policy in country districts: Spatial spillovers of pollution, bio-uniformity and green schemes in Poland. Sci. Total Environ. 2020, 726, 13825. [CrossRef] [PubMed]

24. Czyżewski, B.; Matuszczak, A.; Polcyn, J.; Smędzik-Ambroży, K.; Staniszewski, J. Deadweight loss in environmental pol-icy: The case of the EU number states. J. Clean Prod. 2020, 260, 121064. [CrossRef]

25. Announcement of the Minister of Economy and Work (OBWIESZCZENIE MINISTRA GOSPODARKI I PRACY) z Dnia 1 Lipca 2005 R. W Sprawie Polityki Energetycznej Państwa do 2025 R. M.P.05.42.562. Available online: https://isap.sejm.gov.pl/isap.nsf/ DocDetails.xsp?id=WMP20050420562 (accessed on 18 January 2022).

26. Gotowska, M.; Jakubczak, A. Ocena Porównawcza Odnawialnych Źródeł Energii W Polsce I W Pozostałych Krajach UE. Rocz. Nauk. Stowarzyszenia Ekon. Rol. I Agrobiz. 2011, 12, 1. (In Polish)

27. Implementation of the Sustainable Development Goals in Poland. Realizacja Celów Zrównoważonego Rozwoju w Polsce. 2018. Available online: https:/ /www.gov.pl/web/rozwoj-technologia/monitoring-realizacji-agendy-2030 (accessed on 18 January 2022). (In Polish)

28. Sukiennik, J.; Dokurno, Z.; Fiedor, G. System instytucjonalnej równowagi a proces zmian instytucjonalnych z perspektywy zrównoważonego rozwoju. Ekonomista 2017, 2, 121-143. (In Polish)

29. Baumgärtner, S.; Quaas, M. Sustainability economics-General versus specific, and conceptual versus practical. Ecol. Econ. 2010, 69, 2056-2059. [CrossRef]

30. Abson, D.J.; Fischer, J.; Leventon, J.; Newig, J.; Schomerus, T.; Vilsmaier, U.; von Wehrden, H.; Abernethy, P.; Ives, C.D.; Jager, N.W.; et al. Leverage points for sustainability transformation. Ambio 2016, 46, 30-39. [CrossRef]

31. Sneddon, C.; Howarth, R.; Norgaard, R.B. Sustainable development in a post-Brundtland world. Ecol. Econ. 2006, 57, 253-268. [CrossRef]

32. Bórawski, P.; Bełdycka-Bórawska, A.; Szymańska, E.J.; Jankowski, K.J.; Dubis, B.; Dunn, J.W. Development of renewable Energy sources market and biofuels in the European Union. J. Clean. Prod. 2019, 228, 467-484. [CrossRef] 
33. Geissdoerfer, M.; Vladimirova, D.; Evans, S. Sustainable business model innovation: A review. J. Clean. Prod. 2018, 198, 401-416. [CrossRef]

34. Rashid, A.; Asif, F.M.A.; Krajnik, P.; Nicolescu, C.M. Resource Conservative Manufacturing: An essential change in business and technology paradigm for sustainable manufacturing. J. Clean. Prod. 2013, 57, 166-177. [CrossRef]

35. Naylor, R.L.; Higgins, M.M. The rise in global biodiesel production: Implications for food security. Glob. Food Secur. 2018, 16, 75-84. [CrossRef]

36. OECD; FAO. OECD-FAO Agricultural Outlook 2014; OECD: Paris, France, 2014.

37. Johnston, M.; Holloway, T. A Global Comparison of National Biodiesel Production Potentials. Environ. Sci. Technol. 2007, 41, 7967-7973. [CrossRef] [PubMed]

38. Pimentel, D.; Burgess, M. Biofuel production using food. Environ. Dev. Sustain. 2013, 16, 1-3. [CrossRef]

39. Jasiulewicz, M. Produkcja energii z agrobiomasy w Polsce na tle wybranych krajów Unii Europejskiej. Rocz. Nauk. Stowarzyszenia Ekon. Rol. I Agrobiz. 2015, 17, 2.

40. Kitzing, L.; Mitchel, C.; Morthorst, P.E. Renewable energy policies in Europe: Converging or diverging? Energy Policy 2012, 51, 192-201. [CrossRef]

41. Patrascoiu, M.; Rathbauer, J.; Negrea, M.; Zeller, R. Perspectives of safflower oil as biodiesel source for South Eastern Europe (comparative study: Safflower, soybean and rapeseed). Fuel 2013, 111, 114-119. [CrossRef]

42. Euroactive Biofuels for Transport. Available online: https://www.euractive.com/en/transport/biouels-transport/article15282 (accessed on 18 January 2022).

43. Borychowski, M.; Czyżewski, B. Rozwój Sektora Biopaliw Ciekłych w Polsce i Niemczech. Determinanty Ekonomiczne i Uwarunkowania Instytucjonalne; PWN: Warszawa, Poland, 2017. (In Polish)

44. Lowitzsch, J.; Hoicka, C.E.; van Tulder, F.J. Renewable energy communities under the 2019 European Clean Energy PackageGovernance model for the energy clusters of the future? Renew. Sustain. Energy Rev. 2020, 122, 109489. [CrossRef]

45. Official Journal of the European Union, I. 328/82. Directive (EU) 2018/2001 of the European Parliament and of the Council of 11 December 2018 on the Promotion of the USE of Energy from Renewable Sources (Recast). 2018. Available online: http:/ / refhub.elsevier.com/S1364-0321(19)30697-5/sref68 (accessed on 18 January 2022).

46. Karpinska, L.; Śmiech, S. Will Energy transition in Poland increase the extent and deph of energy poverty? J. Clean Prod. 2021, 328, 129480. [CrossRef]

47. Jones, D.; Moore, C. Renewables Beat Fossil Fuel: A Halyearly Analysis of Europe's Electricity Transitions. Available online: https:/ / ember-climate.org/wp-content/uploads/2020/07/2020-Europe-Half-Year-report.pdf (accessed on 18 January 2022).

48. Renewable Energy Sources: Definition, Types and Stocks. Available online: https://climate.selectra.com/en/environment/ renewable-energy (accessed on 18 January 2022).

49. Laureti, T.; Benedetti, I. Analysing Energy-Saving Behaviours in Italian Households. Stud. Appl. Econ. 2021, 39, 10. [CrossRef]

50. Avanzini, M.; Pinheiro, M.D.; Gomes, R.; Rolim, C. Energy retrofit as an answer to public health costs of fuel poverty in Lisbon social housing. Energy Policy 2021, 160, 112658. [CrossRef]

51. McGinley, O.; Moran, P.; Goggins, J. An Assessment of the Key Performance Indicators (KPIs) of Energy Efficient Retrofits to Existing Residential Buildings. Energies 2022, 15, 334. [CrossRef]

52. Eurostat. Renewable Energy Statistics. Available online: https://ec.europa.eu/eurostat/statistics-explained/index.php?title= Renewable_energy_statistics (accessed on 22 December 2020).

53. Lajdová, Z.; Bielik, P. Vertical price transmission analysis: The case of milk in the Slovak dairy sector. Appl. Stud. Agribus. Commer. 2013, 7, 89-96. [CrossRef] [PubMed]

54. Kharin, S. Price Transmission Analysis: The Case of Milk Products in Russia. Agris-Line Pap. Econ. Inform. 2018, 10, 15-23. [CrossRef]

55. Engle, R.F. Autoregressive Conditional Heteroscedasticity with Estimates of the Variance of United Kingdom Inflation. Econometrica 1982, 50, 987. [CrossRef]

56. Bellerslev, T. Generalized autoregressive conditional heteroskedasticity. J. Econom. 1986, 31, 307-327. [CrossRef]

57. Teresienè, D.; Dubauskas, G. Modelling stock price of Lithuanian manufacture of milk and dairy products companies' volatility with GARCH models. Manag. Theory Stud. Rural. Dev. 2008, 13, 154-161.

58. Daryanto, A.; Sahara, D.A.S.; Singa, A.R. Climate change and milk price volatility in Indonesia. Int. J. Econ. Financ. Issues 2020, 10, 282-288. [CrossRef]

59. Hossain, A. Forecasting volatility of processed milk products in the framework of ARCH model. Int. J. Mod. Sci. Technol. 2018, 3, 190-195.

60. Rajchel, D.; Walawender, A. Energia Odnawialna w Krajach Unii Europejskiej i w Polsce z Uwzględnieniem Gospodarstw Domowych "Stare $i$ Nowe" Problemy Badawcze w Geografii Społecznoekonomicznej; Sitek, S., Ed.; Polskie Towarzystwo Geograficzne Oddział Katowicki, Uniwersytet Śląski Wydział Nauk o Ziemi: Sosnowiec, Poland, 2018. (In Polish)

61. Eurostat. 2016. Available online: https://ec.europa.eu/eurostat/statistics-explained/index.php?title=File:Land_belonging_to_ farms_by_type_of_land,_2016_(\%25_share_on_total_land_area).png (accessed on 18 January 2022).

62. Devis, A.; Van Lipzig, N.P.M.; Demuzere, M. Should future wind speed changes be taken into account in wind farm development? Environ. Res. Lett. 2018, 13, 064012. [CrossRef] 
63. Tobin, I.; Jerez, S.; Vautard, R.; Thais, F.; Van Meijgaard, E.; Prein, A.; Déqué, M.; Kotlarski, S.; Maule, C.F.; Nikulin, G.; et al. Climate change impacts on the power generation potential of a European mid-century wind farms scenario. Environ. Res. Lett. 2016, 11, 034013. [CrossRef]

64. Hueging, H.; Haas, R.; Born, K.; Jacob, D.; Pinto, J.G. Regional Changes in Wind Energy Potential over Europe Using Regional Climate Model Ensemble Projections. J. Appl. Meteorol. Clim. 2013, 52, 903-917. [CrossRef]

65. Tobin, I.; Vautard, R.; Balog, I.; Breon, F.M.; Jerez, S.; Ruti, P.M.; Yiou, P. Assessing climate change impacts on European wind energy from ENSEMBLES high-resolution climate projections. Clim. Change 2015, 128, 99-112. [CrossRef]

66. Hosking, J.S.; MacLeod, D.; Phillips, T.; Holmes, C.R.; Watson, P.; Shuckburgh, E.; Mitchell, D. Changes in European wind energy generation potential within a $1.5^{\circ} \mathrm{C}$ warmer world. Environ. Res. Lett. 2018, 13, 054032. [CrossRef]

67. Barstad, I.; Sorteberg, A.; Mesquita, M.; Dos, S. Present and future offshore wind power potential in northern Europe based on downscaled global climate runs with adjusted SST and sea ice cover. Renew Energy 2012, 44, 398-405. [CrossRef]

68. Bartoszewicz-Burczy, H. Potencjał i energetyczne wykorzystanie biomasy w krajach Europy Środkowej. Energetyka 2012, 12, 860-866. (In Polish)

69. Jasiulewicz, M. Znaczenie rolnictwa w rozwoju energetyki rozproszonej jako formy rozwoju zrównoważonego obszarów wiejskich. Studia Obszarów Wiejskich 2009 | 18 Miejsce obszarów wiejskich w zagospodarowaniu przestrzennym. Rural. Areas Spat. Plan. 2009, 18, 157-169. (In Polish)

70. Farms and farmland in the European Union-Statistics. Available online: https://ec.europa.eu/eurostat/statistics-explained/ index.php?title=Farms_and_farmland_in_the_European_Union_-_statistics\#Farmland_in_2016 (accessed on 18 January 2022).

71. Czyżewski, B.; Guth, M.; Matuszczak, A. The impact of the CAP green programmes on farm productivity and its social contribution. Probl. Ekorozowju/Probl. Sustain. Dev. 2018, 13, 173-183.

72. Petit-Boix, A.; Leipold, S. Circular economy in cities: Reviewing how environmental research aligns with local practices. J. Clean. Prod. 2018, 195, 1270-1281. [CrossRef]

73. Lifset, R.; Graedel, T.E. Industrial ecology: Goals and definitions. A Handb. Ind. Ecol. 2002, 3-15. [CrossRef]

74. Krzyżaniak, M.; Stolarski, M.J.; Warmiński, K. Life cycle assessment of Virginia Maslow production with different fertili-zation options. J. Clean Prod. 2018, 177, 824-836. [CrossRef]

75. Stolarski, M.; Krzyżaniak, W.; Warmiński, K.; Tworkowski, J.; Szczukowski, S. Perennial herbaceous crops as a feedstock for Energy and industrial purposes: Organic and mineral fertilizers versus biomass field and efficient nitro gen utilization. Ind. Crops Prod. 2017, 107, 244-259. [CrossRef]

76. Flach, B.; Lieben, S.; Rosetti, A. EU-28 Biofuels Annual EU Annual 2017; USDA Foreign Agricultural Service: Washington, DC, USA, 2017.

77. EWEA. Wind Energy-the Facts: A Guide to the Technology, Economics and Future of Wind Power; Routledge: London, UK, 2009.

78. Kariniotakis, G.; Mayer Moussafir, D.J.; Chevallaz-Perrier, R.; Usaola, J.; Sanchez, I.; Hatziargyriou, N.D. Anemos: Development of a Next Generation Wind Power Forecasting System for the Large-Scale Integration of Onshore Offshore Wind Farms; EWEC: Madrid, Spain, 2003.

79. Wind EWEA, Energy Scenarios for 2030; European Wind Energy Association: Brussels, Belgium, 2015.

80. Jager-Waldau, A.; Huld, T.; Bodis, K.; Szabo, S. Photovoltaics in Europe after the Paris Agreement. In Proceedings of the 2018 IEEE 7th World Conference on Photovoltaic Energy Conversion (WCPEC) (A Joint Conference of 45th IEEE PVSC, 28th PVSEC \& 34th EU PVSEC), Waikoloa Village, HI, USA, 10-15 June 2018. [CrossRef]

81. Eurostat. 2021. Available online: https:/ / ec.europa.eu/eurostat/databrowser/view/t2020_31/default/table?lang=en (accessed on 18 January 2022).

82. Hajjari, M.; Tabatabaei, M.; Aghbashlo, M.; Ghanavati, H. A review on the prospects of sustainable biodiesel production: A global scenario with an emphasis on waste-oil biodiesel utilization. Renew. Sustain. Energy Rev. 2017, 72, 445-464. [CrossRef]

83. Rouhany, M.; Mantgomery, H. Global Biodiesel Production: The State of the Art and Impact on Climate Change; Tabatabaei, M., Aghbashlo, M., Eds.; Biodiesel from Production to Combustion; Springer: Cham, Switzerland, 2019. [CrossRef]

84. Tabatabaei, M.; Karimi, K.; Horváth, I.S.; Kumar, R. Recent trends in biodiesel production. Biofuel Res. J. 2015, 2, $258-267$. [CrossRef]

85. Tsoutsos, T.; Tournaki, S.; Gkouskos, Z.; Paraíba, O.; Giglio, F.; García, P.Q.; Braga, J.; Adrianos, H.; Filice, M. Quality Characteristics of Biodiesel Produced from Used Cooking Oil in Southern Europe. ChemEngineering 2019, 3, 19. [CrossRef]

86. Bozbas, K. Biodiesel as an alternative motor fuel: Production and policies in the European Union. Renew. Sustain. Energy Rev. 2008, 12, 542-552. [CrossRef]

87. García-Olivares, A.; Solé, J.; Osychenko, O. Transportation in a 100\% renewable energy system. Energy Convers. Manag. 2018, 158, 266-285. [CrossRef]

88. Teske, S.; Pregger, T.; Simon, S.; Naegler, T. High renewable energy penetration scenarios and their implicating for urban energy and transportsystem. Environ. Sustain. 2018, 30, 89-102.

89. Pater, S. Field measurements and energy performance analysis of renewable energy source devices in a heating and cooling system in a residential building in southers Poland. Energy Build. 2019, 199, 115-125. [CrossRef]

90. Settino, J.; Sant, T.; Micallef Ch Furrugia, M.; Spiteri Staines, C.; Licarni, J.; Micallef, A. Overview of solar technologies for electricity, heating and cooling production. Renew Sustain. Energy Rev. 2018, 90, 892-909. [CrossRef] 
91. Perez-Lombard, L.; Ortiz, J.; Pout, C. A review on buildings anergy consumption information. Energy Build. 2008, 40, 394-398. [CrossRef]

92. Stewart, H.; Blayney, D.P. Retail dairy prices fluctuate with the farm value of milk. Agric. Resour. Econ. Rev. 2011, 40, 201-217. [CrossRef]

93. Ghahramani, M.; Thavanewaran, A. A note on GARCH model identifying. Comput. Math. 2008, 55, $2469-2475$.

94. Kumar, D.; Maheswaran, S. Modelling asymmetry and persistence under the impact of sudden changes in the volatility of Indian stock market. IIMB Manag. Rev. 2012, 24, 123-136. [CrossRef]

95. Energy Forum, Analysis and Dialogue. How Poland Can Achieve Increased Greenhouse Gas Emission Reduction Targets by 2030. 2020, p. 11. Available online: https:/ / www.forum-energii.eu/public/upload/articles/files/raport_cel $\% 2055 \% 20$ proc $\% 20$ Forum\%20Energii.pdf. (accessed on 18 January 2022).

96. Miciuła, I. Polityka energetyczna Unii Europejskiej do 2030 roku w ramach zrównoważonego rozwoju. Stud. Pr. WNEiZ 2015, 42, 57-68. [CrossRef]

97. Zaporowski, B. Zrównoważony rozwój źródeł wytwórczych energii elektrycznej. Polityka energetyczna. Energy Policy J. 2016, 19, 35-48. ISSN 1429-6675. (In Polish)

98. Kougias, I.; Taylor, N.; Kakoulaki, G.; Jäger-Waldau, A. The role of photovoltaics for the European Union Green Deal and the recovery plan. Renew. Sustain. Energy Rev. 2021, 144, 111017. [CrossRef]

99. Costoya, X.; Decastro, M.; Carvalho, D.; Arguilé-Pérez, B.; Gómez-Gesteira, M. Combining offshore wind and solar photovoltaic energy to stabilize energy supply under climate change scenarios: A case study on the western Iberian Peninsula. Renew. Sustain. Energy Rev. 2022, 157, 112037. [CrossRef]

100. Strupczewski, A. Analiza i ocena kosztów energii elektrycznej z różnych źródeł energii w Polsce. Nar. Cent. Badań Jądrowych. Rap. NCBJ SJ 2015, 27. Available online: https://ncbj.gov.pl/sites/default/files/ocena_kosztow_wytwarzania_e.e._final.pdf (accessed on 18 January 2022). (In Polish)

101. Chodkowska-Miszczuk, J.; Szymańska, D. Odnawialne źródła energii w produkcji energii elektrycznej. Instytut Geografii, UMK w Toruniu. Naucz. Przedmiotów Przyr. 2012, 41. Available online: https://repozytorium.umk.pl/handle/item/537 (accessed on 18 January 2022). (In Polish)

102. Jasiulewicz, J. Potencjał energetyczny biomasy rolniczej w aspekcie realizacji przez Polskę narodowego celu wskaźnikowego OZE i dyrektyw UE w 2020 roku. Rocz. Nauk. Stowarzyszenia Ekon. Rol. I Agrobiz. 2014, 16, 1. (In Polish)

103. Bórawski, P.; Bełdycka-Bórawska, A.; Jankowski, K.J.; Dubis, B.; Dunn, J.W. Development of wind energy market in the European Union. Renew. Energy 2020, 161, 691-700. [CrossRef]

104. Renewable Energy Prospects for the European Union. Based on REmap Analysis Conducted by the International Renewable Energy Agency in Co-Operation with the European Commission. 2018. Available online: https://www.irena.org/-/media/ Files/IRENA/Agency/Publication/2018/Feb/IRENA_REmap_EU_2018.pdf (accessed on 18 January 2022).

105. Time for Heating 2019. Czas na Ciepłownictwo. 2019, p. 12. Available online: https://www.forum-energii.eu/pl/analizy/ cieplownictwo-2019 (accessed on 18 January 2022). (In Polish).

106. Jäger-Waldau, A. Snapshot of photovoltaics-February 2020. Energies 2020, 13, 930. [CrossRef]

107. Brabec, C.J. Organic photovoltaics: Technology and market. Sol. Energy Mater. Sol. Cells 2004, 83, 273-292. [CrossRef]

108. Green, M.A. Third Generation Photovoltaics; Springer: Berlin/Heidelberg, Germany, 2006.

109. Di Carlo, A.; Lamanna, E.; Nia, N.Y. Photovoltaics. EPJ Web Conf. 2020, 246, 00005. [CrossRef]

110. Kippelen, B.; Brédas, J.-L. Organic photovoltaics. Energy Environ. Sci. 2009, 2, 251-261. [CrossRef] 